\title{
Phytochemical screening and antibacterial activity of different fractions of Operculina turpethum root and leaf
}

\author{
Arif Ahmed ${ }^{1 *}$, Md. Sariful Islam Howlader ${ }^{2}$, Shubhra Kanti Dey ${ }^{1}$, Arpona Hira ${ }^{1}$, Md. \\ Hemayet Hossain ${ }^{3}$, Mir Muhammad Nasir Uddin ${ }^{4}$ \\ ${ }^{1}$ Pharmacy Discipline, Life Science School, Khulna University, Khulna-9208, Bangladesh \\ ${ }^{2}$ Department of Pharmacy, World University of Bangladesh, Dhaka-1205, Bangladesh \\ ${ }^{3}$ BCSIR Laboratories, Dhaka, Bangladesh Council of Scientific and Industrial Research, \\ Dr. Qudrat-E-Khuda Road, Dhaka-1205, Bangladesh \\ ${ }^{4}$ Department of Pharmacy, North South University, Dhaka, Bangladesh \\ Corresponding Author \\ *Arif Ahmed, B.Pharm, E-mail- arif.061126@gmail.com \\ Mobile- +8801913-892102, Pharmacy Discipline, \\ Life Science School, Khulna University, Khulna-9208, Bangladesh. \\ ABSTRACT
}

\begin{abstract}
In Bangladesh, the herb Operculina turpethum is used for otitis media, suppurative sores, burns, conjunctivitis and skin diseases (eczema, abscesses, acne, scabies and warts) although the compounds responsible for the medicinal properties have not been identified. The present study has been undertaken for antibacterial activity of the ethanol, ether and chloroform extract of $O$. turpethum root and leaf. Antibacterial activity has been investigated against Shigella boydii, Shigella flese, Shigella dysenteriae, Escherichia coli, Proteus vulgaris, Salmonella typhi, Hafnia alvei, Staphylococcus epidermidis, Streptococcus pyogenes, Staphylococcus aureus, Enterococcus faecalis by disc diffusion and broth macro-dilution assay. The zone of inhibition has been observed with almost all bacteria with some exceptions. Minimum inhibitory concentrations (MIC) of the extracts were found to be significant.
\end{abstract}

Keywords: Operculina turpethum, Phytochemical screening, Antimicrobial activity, MIC spenomegaly. It is also used to relieve flatulence and

\section{INTRODUCTION}

Operculina turpethum (syn. Ipomoea turpethum) (L.) (Family:Convolvulaceae) is commonly known as Dudh kalmi in Bangladesh, Sanskrit- Kalameshi, Rechani, Kutarana, Bhandi, English-Turpeth root, Indian jalap. O. turpethum is native to Asia (India, Nepal, Bangladesh, Pakistan, Shri Lanka, China, Taiwan, Myanmar, Thailand, Indonesia, Malaysia, Papua New Guinea, \& Philippines), Africa (Kenya, Tanzania, Mozambique, Zimbabwe, Madagascar, Mauritius and Reunion) \& Australia. Four new dammarane-type saponins, operculinosides A-D (14), were isolated from the aerial parts of $O$. turpethum (Wenbing et al., 2011). Root is administered to treat obesity, haemorrhoids, cough, asthma (Sharma and Dravyaguna, 2006), dyspepsia, flatulence, paralysis, gout, rheumatism, melancholia, scorpion sting, and snake bites (Nadkarni, 2007). In constipation, it is an effective laxative. It is used in periodic fevers and in the treatment of anemia accompanied by colic and in the treatment of obesity to decrease fat. It is used to treat dropsy, dyspepsia with constipation and flatulence, gout and rheumatism, and other inflammations (Kumar et al., 2006). The root extract of $O$. turpethum has been used as an antiinflammatory, purgative, and hepatoprotective agent (Riaz, 2009). Ethereal, alcoholic and aqueous extracts of roots of $I$. turpethum (Nishoth) have been screened for their anti- inflammatory activity (Khare et al., 1982). The root of $O$. turpethum is the chief ingredient in the Ayurvedic formulation viz. Avipattikarachurna used for the treatment of gastric ulcer and related gastrointestinal disturbances (Rajashekar et al., 2006). Etheric extract of $O$. turpethum stems showed antioxidant activity (Anbuselvam et al., 2007). The chloroform extract of stem of $I$. turpethum and the crude petroleum ether, chloroform and ethylacetate extracts were screened against thirteen pathogenic bacteria for their antibacterial activities (Rashid et al., 2002). 
Although the crude petroleum ether, chloroform and ethylacetate extracts of stem of $I$. turpethum was screened for antibacterial activity, but no literature is currently available to substantiate antimicrobial activities from $95 \%$ ethanol, ether and chloroform extract of $O$. turpethum leaves and roots, therefore the present study is a part of our on-going antimicrobial and chemical screening of selected $O$. turpethum leaves and roots and designed to provide scientific evidence for its use as a traditional folk remedy by investigating the antimicrobial activities.

\section{MATERIALS AND METHODS}

Plant material: The plant parts of $O$. turpethum was collected from Khulna University, Bangladesh and identified by the experts at Bangladesh National Herbarium, Dhaka, Bangladesh. The necessary plant parts were carefully cleaned and separated from other parts of the plant as well as from undesirable materials. After cutting into small pieces, these were dried under shade with ample aeration. After complete drying, the plant material was grinded into a coarse powder with the help of a suitable grinder. The powdered plant material was weighed using an electric balance, kept in a suitable airtight container and then stored in a dark, cool and dry place for further use.

Extraction: The powdered plant material (crushed roots and leaves) was macerated in 95\% ethanol, ether and chloroform respectively for three days with occasional shaking. It was then filtered through a piece of clean, white cloth and then through a cotton plug to remove the plant debris. The filtrate was evaporated using a rotary vacuum evaporator at a temperature of $50^{\circ} \mathrm{C}$ to yield the crude extract.

Phytochemical screening: The freshly prepared crude extract was qualitatively tested for the presence of chemical constituents, by using the following reagents and chemicals, for example, alkaloids were identified by the dragendorff's reagent, flavonoids with the use of $\mathrm{Mg}$ and $\mathrm{HCl}$, tannins with ferric chloride and potassium dichromate solutions, steroids with Libermann-Burchard reagent and reducing sugars with benedict's reagent (Ghani, 1998; Evans, 1989; Harborne, 1984).

Test microorganism: Four Gram-positive bacteria, $S$. epidermidis, S. pyogenes, $S$. aureus and $E$. faecalis and seven Gram-negative bacteria, S. boydii, S. flese, S. dysenteriae, E. coli, P. vulgaris, S. typhi and $H$. alvei were taken for the test. The bacterial strains used for this investigation were obtained from the bacterial stocks preserved in animal cell culture laboratory of Bangladesh Council of Scientific and Industrial Research, Dr. Qudrat-E-Khuda Road, Dhaka-1205, Bangladesh.

Antibacterial assay: The antibacterial activity was investigated using two methods: disc diffusion and broth macro-dilution assay (Cruickshank, 1968; Andrews, 2001; Ríos et al., 1988). Reference microorganisms from the stock were streaked onto nutrient agar plates and the inoculated plates were incubated overnight at $37^{\circ} \mathrm{C}$. Using a sterile loop, small portion of the subculture was transferred into test tube containing nutrient broth and incubated (2-4 h) at $37^{\circ} \mathrm{C}$ until the growth reached log phase. Nutrient agar media seeded with standard inoculums suspension was poured in Petri-dishes and allowed to solidify. Discs (BBL, Cocksville, USA) impregnated with extract $(250 \mu \mathrm{g} / \mathrm{disc})$, standard antibiotic disc (Kanamycin $30 \mu \mathrm{g} / \mathrm{disc}$, Oxoid Ltd, UK) and blank (solvent ethanol) discs were placed on the Petridishes with sterile forceps and gently pressed to ensure contact with the inoculated agar surface. Finally the inoculated plates were incubated at $37^{\circ} \mathrm{C}$ for $18 \mathrm{~h}$ and the zone of inhibition was measured in millimeters.

The broth macro-dilution assay was carried out to determine the minimum inhibitory concentration (MIC). Stock suspension of the extract was prepared in nutrient broth with tween-80 concentration not exceeding $5 \%$. Serial dilution of the stock was carried out to obtain seven different concentrations $(8,4,2$, $1,0.5$ and $0.25 \mathrm{mg} / \mathrm{ml}$ ) in six vials containing $1 \mathrm{ml}$ each. The same procedure was followed for the standard antibiotic solution of ceftriaxone to obtain seven different concentrations $(8,4,2,1,0.5$ and $0.25 \mu \mathrm{g} / \mathrm{ml}$ ) in six vials containing $1 \mathrm{ml}$ each. Then 1 $\mathrm{ml}$ of freshly grown inoculum was added to each vial and incubated at $37^{\circ} \mathrm{C}$ for $12 \mathrm{~h}$. After incubation period, the vials were checked for turbidity and the lowest concentrations of the extract/standard showing no turbidity were regarded as the MIC of the test substance.

\section{RESULTS}

Phytochemical screening of the ethanol extract of roots of $O$. turpethum indicates the presence of carbohydrates, steroids, gums and saponins and ether and chloroform extract of roots of $O$. turpethum indicates the presence of carbohydrates, steroids, gums, flavonoids and saponins and phytochemical screening of the ethanol, ether and chloroform extract of leaves of $O$. turpethum indicates the presence of 
Am. J. Sci. Ind. Res., 2013, 4(2): 167-172

carbohydrates, steroids, tannins, gums, flavonoids, alkaloids and saponins (Table 1).

Table 1: Phytochemical constituents of extracts of 0 . turpethum

\begin{tabular}{|l|c|c|c|c|c|c|c|}
\hline \multicolumn{1}{|c|}{ Extracts } & Steroids & Alkaloids & $\begin{array}{c}\text { Reducing } \\
\text { Sugars }\end{array}$ & Tannins & Gums & Flavonoids & Saponins \\
\hline Ethanol extract of O. turpethum root & + & - & + & - & + & - & + \\
\hline Ether extract of O. turpethum root & + & - & + & - & + & + & + \\
\hline Chloroform extract of O. turpethum root & + & - & + & - & + & + & + \\
\hline Ethanol extract of O. turpethum leaf & + & + & + & + & + & + \\
\hline Ether extract of O. turpethum leaf & + & + & + & + & + & + \\
\hline Chloroform extract of O. turpethum leaf & + & + & + & + & + & + \\
\hline
\end{tabular}

$+=$ Presence of constituents; - = Absence of constituents

In the antibacterial assay the ether and chloroform extract of root and leaf inhibited all bacteria. In disk diffusion assay the ethanol extract of root inhibited all the microorganisms except $P$. vulgaris and $E$. faecalis (Table 2). The highest zone of inhibition was $8.9 \mathrm{~mm}$ against $S$. aureus. Zone of inhibition for the standard Kanamycin discs ranged between 24.30 to $33.80 \mathrm{~mm}$ (Table 2).

The data obtained from broth macro dilution assay for determining MIC is presented in (Table 3). Minimum inhibitory concentration (MIC) of the ethanol extract of root was $8000 \mu \mathrm{g} / \mathrm{ml}$ for $P$. vulgaris, S. typhi, $H$. alvei and E. faecalis; $4000 \mu \mathrm{g} / \mathrm{ml}$ for S. boydii; 2000 $\mu \mathrm{g} / \mathrm{ml}$ for $S$. dysenteriae, E. coli, S. epidermidis, $S$.

pyogenes and $S$. aureus. MIC of the ether extract of root was $8000 \mu \mathrm{g} / \mathrm{ml}$ for S. flese, P. vulgaris, S. typhi, and E. faecalis; $4000 \mu \mathrm{g} / \mathrm{ml}$ for S. boydii and H. alvei;
$1000 \mu \mathrm{g} / \mathrm{ml}$ for E. coli, S. epidermidis, S. pyogenes and $S$. aureus. MIC of the chloroform extract of root was $8000 \mu \mathrm{g} / \mathrm{ml}$ for $P$. vulgaris and E. faecalis; 2000 $\mu \mathrm{g} / \mathrm{ml}$ for $S$. boydii, S. flese and S. typhi; $1000 \mu \mathrm{g} / \mathrm{ml}$ for $S$. dysenteriae, $E$. coli, $H$. alvei and $S$. epidermidis; $500 \mu \mathrm{g} / \mathrm{ml}$ for $S$. pyogenes and $S$. aureus. MIC of the ethanol extract of leaf was 4000 $\mu \mathrm{g} / \mathrm{ml}$ for $P$. vulgaris, S. typhi, H. alvei and E. faecalis; $2000 \mu \mathrm{g} / \mathrm{ml}$ for S. boydii, S. flese, S. dysenteriae, $E$. coli, S. epidermidis, S. pyogenes and S. aureus. MIC of the ether extract of leaf was $8000 \mu \mathrm{g} / \mathrm{ml}$ for $P$. vulgaris; $4000 \mu \mathrm{g} / \mathrm{ml}$ for S. typhi, H. alvei and $E$. faecalis; $2000 \mu \mathrm{g} / \mathrm{ml}$ for $S$. boydii, S. flese, $S$. dysenteriae, E. coli, S. epidermidis, S. pyogenes and $S$. aureus. MIC of the chloroform extract of leaf was $8000 \mu \mathrm{g} / \mathrm{ml}$ for $P$. vulgaris; $4000 \mu \mathrm{g} / \mathrm{ml}$ for S. typhi, $H$. alvei and E. faecalis; $2000 \mu \mathrm{g} / \mathrm{ml}$ for $S$. boydii, $S$. flese, S. dysenteriae, S. epidermidis, S. pyogenes and $S$. aureus; $1000 \mu \mathrm{g} / \mathrm{ml}$ for E. coli.

Table 2: Disc diffusion assay of different extracts of 0 . turpethum root and leaf

\begin{tabular}{|c|c|c|c|c|c|c|c|}
\hline & \multicolumn{7}{|c|}{ Diameter of zone of inhibition (mm) } \\
\hline Bacterial strain & $\mathbf{I}$ & II & III & IV & $\mathbf{V}$ & VI & $\begin{array}{c}\text { Kanamycin (30 } \\
\mu \mathrm{g} / \mathrm{disc})\end{array}$ \\
\hline \multicolumn{8}{|l|}{ Gram negative bacteria } \\
\hline Shigella boydii & 4 & 4.8 & 5.7 & 5.1 & 5.8 & 6.1 & 32.4 \\
\hline Shigella flese & 3.6 & 4.1 & 5.2 & 5.4 & 5.5 & 5.6 & 24.3 \\
\hline Shigella dysenteriae & 5.1 & 5.6 & 6.8 & 5.6 & 5.8 & 5.9 & 24.3 \\
\hline Escherichia coli & 5.6 & 6.1 & 7.2 & 5.9 & 5.9 & 6.7 & 29.3 \\
\hline Proteus vulgaris & 0 & 2 & 3.2 & 4.3 & 3.7 & 3.9 & 33.1 \\
\hline Salmonella typhi & 3.8 & 4 & 5.1 & 4.7 & 5.1 & 4.9 & 33.4 \\
\hline Hafnia alvei & 4.1 & 4.8 & 6.3 & 4.5 & 5 & 4.3 & 33.1 \\
\hline \multicolumn{8}{|l|}{ Gram positive bacteria } \\
\hline Staphylococcus epidermidis & 5.9 & 6.4 & 7.6 & 6.2 & 6.2 & 6.5 & 25.8 \\
\hline Streptococcus pyogenes & 6.2 & 7.1 & 8.6 & 6.7 & 6.8 & 6.3 & 26.2 \\
\hline Staphylococcus aureus & 6.1 & 7 & 8.9 & 6.8 & 6.3 & 6 & 28.3 \\
\hline Enterococcus faecalis & 0 & 1.6 & 2.9 & 4.9 & 4.1 & 4.3 & 33.8 \\
\hline
\end{tabular}


Am. J. Sci. Ind. Res., 2013, 4(2): 167-172

I=ethanol extract of root of $O$. turpethum $(250 \mu \mathrm{g} / \mathrm{ml})$, II=ether extract of root of $O$. turpethum $(250 \mu \mathrm{g} / \mathrm{ml})$, III=chloroform extract of root of $O$. turpethum $(250 \mu \mathrm{g} / \mathrm{ml})$, IV=ethanol extract of leaf of $O$. turpethum $(250 \mu \mathrm{g} / \mathrm{ml}), \mathrm{V}=$ ether extract of leaf of O. turpethum $(250 \mu \mathrm{g} / \mathrm{ml}), \mathrm{Vl}=$ chloroform extract of leaf of $O$. turpethum $(250 \mu \mathrm{g} / \mathrm{ml})$.

Table 3: MICs of $O$. turpethum root and leaf extracts

\begin{tabular}{|c|c|c|c|c|c|c|c|}
\hline 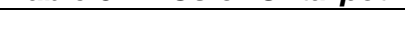 & \multicolumn{7}{|c|}{ Minimum Inhibitory Concentration (MIC) } \\
\hline Bacterial strain & I & II & III & IV & $\mathbf{V}$ & VI & $\begin{array}{c}\text { Ceftriaxone } \\
(\mu \mathrm{g} / \mathrm{ml})\end{array}$ \\
\hline \multicolumn{8}{|l|}{ Gram negative bacteria } \\
\hline Shigella boydii & 4000 & 4000 & 2000 & 2000 & 2000 & 2000 & 0.5 \\
\hline Shigella flese & 8000 & 8000 & 2000 & 2000 & 2000 & 2000 & 1 \\
\hline Shigella dysenteriae & 2000 & 2000 & 1000 & 2000 & 2000 & 2000 & 0.25 \\
\hline Escherichia coli & 2000 & 1000 & 1000 & 2000 & 2000 & 1000 & 0.25 \\
\hline Proteus vulgaris & 8000 & 8000 & 8000 & 4000 & 8000 & 8000 & 2 \\
\hline Salmonella typhi & 8000 & 8000 & 2000 & 4000 & 4000 & 4000 & 2 \\
\hline Hafnia alvei & 8000 & 4000 & 1000 & 4000 & 4000 & 4000 & 1 \\
\hline \multicolumn{8}{|l|}{ Gram positive bacteria } \\
\hline Staphylococcus epidermidis & 2000 & 1000 & 1000 & 2000 & 2000 & 2000 & 1 \\
\hline Streptococcus pyogenes & 2000 & 1000 & 500 & 2000 & 2000 & 2000 & 0.5 \\
\hline Staphylococcus aureus & 2000 & 1000 & 500 & 2000 & 2000 & 2000 & 0.5 \\
\hline Enterococcus faecalis & 8000 & 8000 & 8000 & 4000 & 4000 & 4000 & 2 \\
\hline
\end{tabular}

I=ethanol extract of root of $O$. turpethum $(\mu \mathrm{g} / \mathrm{ml})$, II=ether extract of root of $O$. turpethum $(\mu \mathrm{g} / \mathrm{ml})$, III=chloroform extract of root of $O$. turpethum $(\mu \mathrm{g} / \mathrm{ml}), \mathrm{IV}=$ ethanol extract of leaf of $O$. turpethum $(\mu \mathrm{g} / \mathrm{ml}), \mathrm{V}=$ ether extract of leaf of $O$. turpethum $(\mu \mathrm{g} / \mathrm{ml}), \mathrm{Vl}=\mathrm{chloroform}$ extract of leaf of $O$. turpethum $(\mu \mathrm{g} / \mathrm{ml})$.

\section{DISCUSSIONS}

The ethanol extracts of root and leaf showed moderate antibacterial activity whereas ether and chloroform extracts of root and leaf showed relatively higher antibacterial activity in both the assays. Although the ethanol extract of root did not show antibacterial activity against $E$. faecalis and $P$. vulgaris but inhibited the same microorganism in broth marco dilution assay. However, the MIC was obtained at a higher concentration $(8000 \mu \mathrm{g} / \mathrm{ml})$ than the extract content in the disc $(250 \mu \mathrm{g} / \mathrm{ml})$. Therefore, concentration may play a role for the observed activity in latter experiment. Antibacterial activity offered by non polar compound(s) may also be a reason as it may fail to diffuse in agar media to exhibit antibacterial activity in disc diffusion assay (Anderson et al., 1988). A difference in inoculums size used for the assay can lead to variable results for a given sample. In the present study we adjusted to keep the inoculums size as close to the recommended standard of $5 \times 10^{5} \mathrm{CFU} / \mathrm{ml}$ (Ríos et al., 1988).

The plant is also reported to contain saponins. There is growing interest in natural saponins caused as much by the scientific aspects extraction and structural analysis of these compounds, as by the fact of their wide spectrum of pharmacological activities; for instance, bactericidal, antiviral, cytotoxic, analgesic, anti-inflammatory, anti-cancer and antiallergic (Attele et al., 1999). Phytochemical constituents such as tannins, flavonoids, alkaloids and several other aromatic compounds of plant that serve as defense mechanisms against predation by many microorganisms, insects and herbivores. The antibacterial activity of flavonoids is probably due to their ability to complex with extracellular and soluble proteins and to complex with bacterial cell walls (Doss et al., 2009; Doss et al., 2011a; Doss et al., $2011 b)$. Several reports are available in support of antimicrobial activity of saponins against bacterial and fungal pathogens (Gopish and Kannabiran, 2008).The alkaloids are known to have antimicrobial and anti-parasitic properties. Verpoorte have reported about 300 alkaloids showing such activity (Verpoorte, 1998). Similar results on antibacterial activity were reported on related species of the genus Mahonia (Duraiswamy, 2006; Livia et al., 2004; Li et al., 2007).

\section{CONCLUSION}

The present study provides a rationale for the use of $O$. turpethum in traditional medicine in Bangladesh. Further studies like HPLC and LC-MS can be carried out to confirm whether the observed activity of the root and leaf is due to the presence of (-)epicatechin-3-O- $\beta$-glucopyranoside, the compound responsible for the antimicrobial activity of the leaves and root. The present results therefore offer a scientific basis for traditional use of the plant $O$. turpethum against infection by burns or wounds. But in vivo studies on the medicinal plant are necessary and should seek to determine toxicity of active 
constituents, their side effects, serum-attainable levels, pharmacokinetic properties and diffusion in different body sites. The antibacterial activity could be enhanced if active components are purified and adequate dosage is determined for proper administration. It goes a long way in curbing administration of inappropriate concentration, a common practice among many traditional practitioners. This represents a preliminary report on the antibacterial activity of the medicinal plant $O$. turpethum in Bangladesh and for rational use of the traditional plant it requires further scientific study as necessary on it.

\section{ACKNOWLEDGEMENT}

We are thankful to Md. Hemayet Hossain, BCSIR Laboratories, Dhaka, Bangladesh Council of Scientific and Industrial Research, Dr. Qudrat-EKhuda Road, Dhaka-1205, Bangladesh for providing us with reagents and labs. Ceftriaxone was obtained from Drug International Ltd, Bangladesh.

\section{REFERENCES}

Anbuselvam, C., Vijayavel, $\mathrm{K}$ and Balasubramanian, M.P (2007). Protective effect of Operculina turpethum against 7, 12 dimethylbenz (a) anthracene induced oxidative stress with reference to breast Cancer in experimental rats. Chem-Biol. Interact. 168 (3): 229236.

Anderson, J.E., Chang, C.J and McLaughlin, J.L (1988). Bioactive components of Allamanda schottii. J. Nat. Prod. 51: 307-308.

Andrews, J.M (2001). Determination of minimum inhibitory concentrations. J. Antimicrob. Chemother. 48: 5-16.

Attele, A.S., Wu, J.A and Yuan, C (1999). Analgesic effects of different aucpoint stimulation frequencies in humans. Biochem. Pharmacol. 58: 1685-1693.

Cruickshank, R (1968). Medical Microbiology: A Guide to Diagnosis and Control of Infection, Edinburgh/London: E. and S. Livingstone Ltd, pp: 888.

Doss, A., Muhamed Mubarack, $\mathrm{H}$ and Dhanabalan, $\mathrm{R}$ (2009). Antibacterial activity of tannins from Solanum trilobatum Linn. Leaves. Indian J. Sci. Tech. 2(2): 4143.

Doss, A., Vijaya Santhi, M., Parivuguna, V and Venkataswamy, R (2011a). Antimicrobial effects of the Flavonoid fractions of Mimosa pudica L. Leaves. J. Pharm. Res. 4(5): 1438-1439.

Doss, A., Parivuguna, V., Vijaya Santhi, M and Sruthi, S (2011b). Antibacterial and preliminary phytochemical analysis of Medicago sativa L. against some microbial pathogens. Ind. J. Sci. Tech. 4(5): 550-552.

Duraiswamy, B., Sagar, K.M., Subhashini, V., Dhanraj, S.A and Suresh, B (2006). Studies on the antimicrobial potential of Mahonia leschenaultia Takeda root and root bark. Ind. J. Pharmaceut. Sci. 68(3): 389-391.
Evans, W.C (1989). Trease and Evan's Textbook of Pharmacognosy. 13th ed., Cambidge University Press, London, pp: 546.

Ghani, A (1998). Medicinal Plants of Bangladesh, Asiatic Society Dhaka, 1st edition, pp: 13.

Gopish, K.V and Kannabiran, K (2008). Antimicrobial activity of saponin fractions of the leaves Gymnema sylvestre and Eclipta prostrata. World J. Microbiol. Biotech. 24: 2737-2740.

Harborne, J.B (1984). Phytochemal methods (A guide to modern techniques to plantanalysis). 3rd ed. Chapman and Hall, London.

Khare, A.K., Srivastava, M.C., Tewari, J.P., Puri, J.N., Singh, S and Ansari, N.A (1982). A preliminary study of Anti- Inflammatory activity of Ipomoea turpethum (nishoth). Indian drugs, pp: 224-228.

Kumar, S.V., Sujatha, C., Syamala, J., Nagasudha, B and Mishra, S.H (2006). Protective effect of root extract of Operculina turpethum linn. against paracetamolinduced hepatotoxicity in rats. Indian J. Pharm. Sci. 68(1): 32-35.

Li, A., Zhu, Y., Li, $X$ and Tian, $X$ (2007). Antimicrobial activity of four species of Berberidaceae. Fitoterapia 78: 379-381.

Livia, S., Daniela, K., Darina, L., Daniela, K and Viktor, K (2004). Antimicrobial activity of Mahonia aquifolium crude extract and its major isolated alkaloids. Phytother. Res. 18: 674-676.

Nadkarni, K.M and Nadkarni, A.K (2007). Indian Materia Medica, Vol-I, Bombay Popular Mumbai, pp: 691-694.

Rajashekar, M.B., Laakshmayya, Pramod Kumar Nitin, K.M and Ramachandra, S.S (2006). Pharmacological Screening of Root of Operculina turpethum and its formulations. Acta Pharmaceutica Sciencia 48: 11-17.

Rashid, M.H., Gafur, M.A., Sadik, M.G and Rahman, A.A (2002). Antibacterial and Cytotoxic Activities of Extracts and Isolated Compounds of Ipomoea turpethum. Pak. J. Bio. Sci. 5(5): 597-599.

Riaz, A., Sarfaraz, A., Nizam, U.K and Hasnain, A (2009). Operculina turpethum Attenuates Nnitrosodimethylamine induced toxic liver injury and Clastogenicity in rats. Chem.-Biol. Interactions 181(2): 145-153.

Ríos, J.L., Recio, M.C and Villar, A (1988). Screening methods for natural products with antimicrobial activity: a review of the literature. J. Ethnopharmacol. 23: 127149.

Sharma, P.V and Dravyaguna, V (2006). Chaukhamba Bharti, Varanasi (India), Vol-II, pp: 419-422.

Verpoorte, R (1998). Antimicrobially active alkaloids in Alkaloids: biochemistry, ecology and medicinal applications, Eds. Margaret F. Robert and Michael Wink, Springer publication, pp: 397-426.

Wenbing, D., Zeng, F., Xu, L., Chen, Y., Wang, Y and Wei, $X$ (2011). Bioactive Dammarane-Type Saponins from Operculina turpethum. J. Nat. Prod. 74(9): 1868-1874. 